\begin{tabular}{|c|cc} 
JURNAL BIOTERDIDIK: WAHANA EKSPRESI ILMIAH & \begin{tabular}{c} 
e-ISSN: \\
$2621-5594$ \\
p-ISSN: \\
\hline Jurnal Bioterdidik
\end{tabular} Vol. 9 No. 3, Desember 2021, page. 234-241 \\
$\frac{\text { http://jurnal.fkip.unila.ac.id/index.php/JBT/ }}{\text { doi: } 10.23960 / \text { jbt.v9i3.23078 }}$ & \\
\hline
\end{tabular}

\title{
Hubungan Self Efficacy Terhadap Motivasi Belajar Biologi Siswa Kelas XI Pada Pembelajaran Daring
}

\author{
Sindia Dwi Yolandita*, Nurul Fauziah \\ Pendidikan Biologi, Fakultas Keguruan dan Ilmu Pendidikan, Universitas Islam Riau, Jl. Kaharuddin \\ Nation No. 113 Pekanbaru, Indonesia \\ *e-mail: sindiadwiyolandita@student.uir.ac.id
}

Online Published: December 30, 2021

\begin{abstract}
The Relationship of Self Efficacy to The Motivation of Students to Learn Biology Class XI on Online Learning. This research is correlation research. This study aims to determine the relationship between self-efficacy and motivation to learn biology in class XI SMA Negeri 14 Pekanbaru in the 2020/2021 academic year. The instruments used in data collection are observation, interviews, questionnaires, and documentation. This research was conducted on April 26 to June 3, 2021. The sampling technique in this study used a saturated sampling technique. The number of samples in this study was 180 students. The questionnaire distributed consisted of 30 statements. The results of data analysis correlation coefficient $\left(r_{\text {count }}\right)$ of 0,22 with a significant level of 5\% has a correlation in the low category. From hypothesis testing, it was obtained $t_{\text {count }}(3,0)>t_{\text {table }}(1,66)$. This means that Ho is rejected, and Ha is accepted. Then from the results of the analysis of the coefficient of determination of the self-efficacy variable $(X)$ it gave a positive contribution to learning motivation $(Y)$ which was obtained by 5\% while $95 \%$ was determined by other variables or factors that influenced student learning motivation which were not discussed in this study.
\end{abstract}

Keywords: motivation, biology learning, self-efficacy

Abstrak: Hubungan Self efficacy terhadap Motivasi Belajar Biologi Siswa Kelas XI Pada Pembelajaran Daring. Penelitian ini adalah penelitian korelasi. Penelitian ini bertujuan untuk mengetahui hubungan self-efficacy terhadap motivasi belajar biologi kelas XI SMA Negeri 14 Pekanbaru Tahun Ajaran 2020/2021. Instrumen yang digunakan dalam pengumpulan data adalah, observasi, wawancara, angket dan dokumentasi. Penelitian ini dilaksanakan pada tanggal 26 April sampai dengan 3 Juni 2021. Teknik pengambilan sampel pada penelitian ini menggunakan teknik sampling jenuh. Jumlah sampel dalam penelitian ini adalah 180 siswa. Angket yang disebarkan terdiri dari 30 pernyataan. Hasil analisis data koefisien korelasi ( $\mathrm{r}_{\text {hitung }}$ ) sebesar 0,22 dengan taraf signifikan 5\% memiliki korelasi dalam kategori rendah. Dari pengujian hipotesis diperoleh thitung $(3,0)>t_{\text {tabel }}(1,66)$. Hal ini berarti Ho ditolak dan Ha diterima. Kemudian dari hasil analisis koefisien determinasi variabel self-efficacy $(\mathrm{X})$ memberikan sumbangan positif terhadap motivasi belajar (Y) yang diperoleh siswa sebesar 5\% sedangkan 95\% ditentukan oleh variabel atau faktor lain yang mempengaruhi motivasi belajar siswa yang tidak dibahas dalam penelitian ini.

Kata kunci: motivasi belajar, pembelajaran biologi, self-efficacy 


\section{PENDAHULUAN}

Pendidikan adalah bagian yang tidak terpisahkan dari kehidupan manusia, mulai lahir hingga lanjut usia senantiasa belajar terhadap lingkungan di sekitarnya (Aryanti dan Muhsin, 2020). Pendidikan merupakan usaha yang terencana untuk mewujudkan suasana belajar dan proses pembelajaran agar siswa secara aktif dapat mengembangkan potensi yang ada pada dirinya. Pendidikan sangat berkaitan erat dengan proses pembelajaran di sekolah terutama untuk hasil belajar. Salah satu mata pelajaran di Sekolah yang dapat memberikan peran dan pengalaman bagi siswa adalah pembelajaran biologi. Dalam pembelajaran Biologi dilakukan dengan berbagai upaya, salah satunya melalui peningkatan motivasi dalam belajar.

Belajar adalah proses perubahan perilaku sebagai hasil interaksi individu dengan lingkungannya. Perubahan perilaku terhadap hasil belajar bersifat berkelanjutan, fungsional, positif, aktif dan terarah, dengan terjadinya proses belajar maka pemahaman seseorang akan semakin bertambah (Pane dan Dasopang, 2017). Siswa belajar karena didorong oleh kekuatan mental. Kekuatan mental itu berupa keinginan, perhatian, kemauan, dan cita-cita. Siswa belajar karena terbentuk adanya rasa keyakinan diri akan kemampuan yang dimiliki dalam menyelesaikan tugas. Keyakinan diri disebut juga dengan self-efficacy.

Self-efficacy merupakan salah satu aspek pengetahuan tentang diri atau selfknowledge yang paling berpengaruh dalam kehidupan manusia sehari-sehari. Hal ini disebabkan self-efficacy yang dimiliki ikut mempengaruhi individu dalam menentukan tindakan yang akan dilakukan untuk mencapai suatu tujuan, termasuk di dalamnya perkiraan berbagai kegiatan yang akan dihadapi (Ghufron dan Risnawati, 2017). Selfefficacy yang rendah pada siswa akan sangat berpengaruh terhadap proses pembelajaranya. Hal ini akan berdampak pada siswa menjadi malas untuk belajar, rasa cemas yang tinggi dalam mengerjakan tugas, kemampuan diri yang rendah terhadap pembelajaran, dan rasa cepat menyerah terhadap pembelajaran (Amir,2016).

Siswa yang memiliki self-efficacy yang tinggi, adalah siswa yang yakin bahwa dirinya mampu menyelesaikan tugas dengan baik. Sedangkan siswa yang memiliki selfefficacy yang rendah cenderung kebingungan dan bermasalah dalam menyelesaikan tugasnya. Adanya keyakinan diri yang dimiliki siswa akan kemampuannya, maka siswa akan termotivasi dalam menyelesaikan persoalan yang terdapat di dalam pembelajaran biologi. Keyakinan diri yang ada pada siswa dalam pembelajaran dapat menumbuhkan keinginan yang kuat untuk motivasi belajar siswa.

Motivasi merupakan keseluruhan daya penggerak di dalam diri siswa yang menimbulkan kegiatan belajar, yang menjamin kelangsungan dari kegiatan belajar dan memberikan arah pada kegiatan belajar. Motivasi belajar adalah faktor psikis yang bersifat non intelektual. Siswa yang memiliki motivasi belajar yang tinggi, akan mempunyai banyak energi untuk melakukan kegiatan belajar (Sardiman, 2018). Jika motivasi belajar siswa cenderung rendah, hal ini menunjukkan bahwa siswa tersebut kurang yakin terhadap kemampuan yang dimiliki oleh dirinya dan merasa kurang kompeten dalam memahami serta memenuhi tuntutan akademik yang ada dihadapan mereka.

Hasil observasi pada siswa kelas XI SMA Negeri 14 Pekanbaru menunjukkan bahwa siswa kurang aktif pada saat proses pembelajaran berlangsung. ketika guru memberikan pertanyaan kepada siswa, beberapa siswa cenderung pasif, tidak mau menjawab pertanyaan dari guru, walaupun sebenarnya ia mengetahui jawabannya.. Hasil wawancara pada 10 orang siswa kelas XI SMA Negeri 14 Pekanbaru, menunjukkan 
bahwa sebagian siswa masih ada yang malu bertanya dan malu untuk mengungkapkan pendapat karena kurang percaya diri. Selain itu sebagian siswa juga terkadang masih telat dalam mengumpulkan tugas yang diberikan oleh guru.

Self-efficacy dapat berpengaruh terhadap motivasi belajar siswa, dengan adanya keyakinan diri yang dimiliki siswa akan kemampuannya, maka siswa akan termotivasi untuk melakukan sesuatu yang ingin dicapai dalam hal belajar. Sejalan dengan penelitian yang dilakukan Zega (2020) menyatakan bahwa pada uji korelasi product moment didapatkan 0,715 hubungan antara self-efficacy terhadap motivasi belajar sebesar 51,20\%.

Berdasarkan hal tersebut, maka peneliti ingin melakukan penelitian dengan judul "Hubungan Self Efficacy Terhadap Motivasi Belajar Biologi Siswa Kelas XI SMA Negeri 14 Pekanbaru Tahun Ajaran 2020/2021".

\section{METODE}

Penelitian ini merupakan penelitian kuantitatif. Penelitian dilaksanakan di kelas XI SMA Negeri 14 Pekanbaru. Populsi dalam penelitian ini adalah 180 siswa. Teknik pengambilan sampel menggunakan teknik sampel jenuh.

Teknik pengumpulan data dalam penelitian ini menggunakan teknik observasi, angket, wawancara, dan dokumentasi. Data hasil penelitian dianalisis dalam dua bentuk, yaitu analisis deskriptif dan analisis inferensial.

Tekik analisis data dalam penelitian ini adalah analisis data deskriptif. Menurut Sudijono (2018) untuk menganalisis angket yang telah diperoleh maka peneliti mengubah data tersebut dalam bentuk persentase dengan menggunakan rumus persentase, yaitu:

$$
\mathrm{P}=\frac{\mathrm{F}}{\mathrm{N}} \times 100 \%
$$

Keterangan:

$\mathrm{P}$ : Persentase

F : Frekuensi Skor Jawaban

$\mathrm{N}$ : Jumlah Responden

Kegunaan uji person product moment atau analisis korelasi adalah mencari hubungan variabel bebas (X) dengan variabel terikat (Y) uji ini lebih terkenal dengan analaisi korelasi pearson product moment (Riduwan, 2016). Rumus nya adalah sebagai berikut:

Keterangan:

$$
\operatorname{rxy}=\frac{n\left(\sum X Y\right)-\left(\sum X\right) \cdot\left(\sum Y\right)}{\sqrt{\left\{n \cdot \sum X^{2}-\left(\sum X\right)^{2}\right\} \cdot\left\{\mathrm{n} \cdot \sum Y^{2}-\left(\sum Y\right)^{2}\right\}}}
$$

$\mathrm{r}_{\mathrm{xy}}=$ Koefisien korelasi

$\sum \mathrm{Xi}=$ Jumlah skor item

$\sum \mathrm{Yi}=$ Jumlah skor total (seluruh item)

$\mathrm{n} \quad=$ Jumlah responden

Nilai korelasi yang diperoleh kemudian dikategorikan berdasarkan interval koefisien dan tingkat hubungan sebagai berikut: 
Tabel 1. Interpretasi Koefesien Korelasi

\begin{tabular}{cc}
\hline Interval Koefisien & Tingkat Hubungan \\
\hline $0,00-0,199$ & Sangat rendah \\
\hline $0,20-0,399$ & Rendah \\
\hline $0,40-0,599$ & Cukup \\
\hline $0,60-0,799$ & Kuat \\
\hline $0,80-1,000$ & Sangat Kuat \\
\hline
\end{tabular}

Langkah-langkah yang digunakan dalam pengujian ini adalah sebagai berikut: Pengujian Hipotesis. Hipotesis $\left(\mathrm{H}_{0}\right.$ dan $\left.\mathrm{H}_{\mathrm{a}}\right)$ dalam bentuk statistika:

$\mathrm{H}_{0}: \mathrm{p}=0$

$\mathrm{H}_{\mathrm{a}}: \mathrm{p} \neq 0$

Menghitung nilai t pada korelasi PPM menggunakan rumus menurut Riduwan (2015) sebagai berikut:

Keterangan:

$$
\mathrm{t}_{\text {hitung }}=\frac{r \sqrt{n-2}}{\sqrt{1-r^{2}}}
$$

$t_{\text {hitung }}$ : Nilai $\mathrm{t}$

r : Nilai Koefisien Korelasi

n : Jumlah Sampel

Besar kecilnya sumbangan self-efficacy (X) dengan motivasi belajar (Y) dapat ditentukan dengan rumus koefisien determinan sebagai berikut:

$$
\mathrm{KP}=\mathrm{r}^{2} \times 100 \%
$$

Keterangan:

KP : Nilai Determinasi

r : Nilai Koefisien Korelasi

Sumber: Riduwan (2015)

HASIL DAN PEMBAHASAN

Hasil analisis angket self-efficacy siswa. Hasil analisis angket self-efficacy yang dilakukan pada sampel yang berjumlah 180 siswa dapat dilihat pada gambar 1 berikut ini:

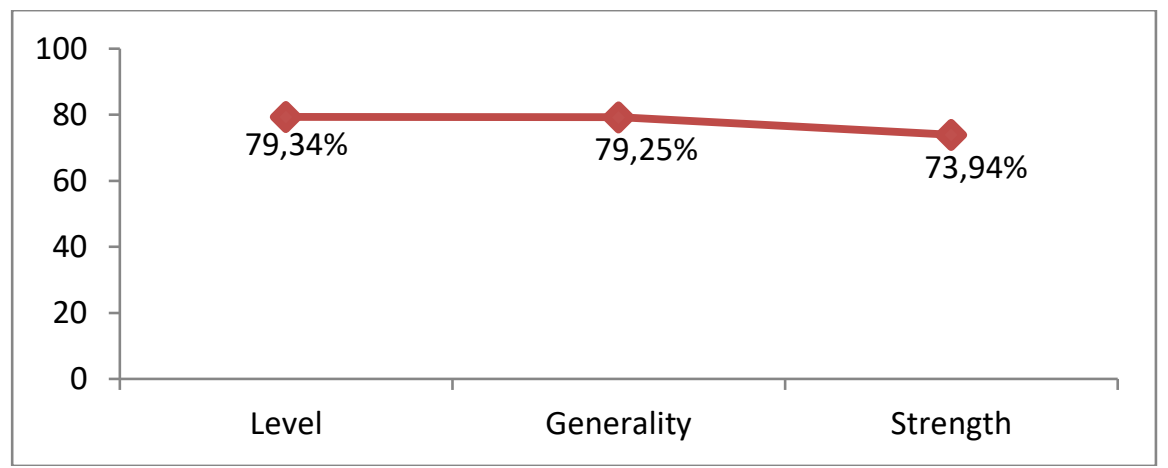

Gambar 1. Persentase Seluruh Aspek Self-efficacy

Gambar 1 menunjukkan bahwa dari ketiga aspek self-efficacy memiliki persentase berbeda-beda. Aspek level memiliki persentase siswa lebih tinggi disbandingkan dengan aspek generality sedangkan aspek strength memiliki persentase siswa yang rendah. Hal ini menunjukkan bahwa siswa kelas XI SMA Negeri 14 Peknabaru memiliki self-efficacy 
yang tinggi pada aspek level dan generality tetapi memiliki self-efficacy yang rendah pada aspek stenght.

Berdasarkan hasil wawancara siswa diperoleh bahwa siswa dengan self-efficacy tinggi pada aspek level sudah dikatakan tinggi menunjukkan bahwa siswa sudah yakin terhadap dirinya dalam menyelesaikan tugas Biologi yang sulit sehingga siswa tidak mudah menyerah saat meghadapi kesulitan dalam memahami materi Biologi. Selain itu siswa juga memiliki usaha yang tinggi dalam agar mampu mencapai target dan tujuan dalam belajarnya. Siswa dengan self-efficacy tinggi akan menunjukkan bahwa siswa mampu untuk mempersepsi dirinya bahwa ia mampu dalam menyelesaikan tugas yang sulit sehingga siswa tidak mudah menyerah saat mengalami kesulitan yang dihadapinya.

Siswa dengan self-efficacy rendah akan meyakini bahwa dirinya hanya dapat mengerjakan soal-soal yang mudah dan tidak merasa tentantang untuk menetapkan suatau tujuan atau target dalam melalukan aktifitas pada saat belajar (Movenda, Kurniati, dan Rizmahardian, 2018). Berdasarkan hasil wawancara siswa diperoleh bahwa siswa dengan self-efficacy tinggi pada aspek generality sudah dikatakan tinggi menunjukkan bahwa siswa memiliki keyakinan diri terhadap kemampuan dalam belajar, mereka akan terus berusaha mempereloleh nilai yang baik dengan kemampuannya sendiri.

Siswa dengan self-efficacy tinggi akan meningkatkan usahanya ketika mengalami kegagalan dan tetap fokus pada aktifitasnya ketika menemui hambatan. Sedangkan siswa dengan self-efficacy rendah menandakan bahwa siswa tidak dapat bertahan ketika menghadapi hambatan atau kegagalan. Selain itu siswa udah terpengaruh oleh lingkungan yang mempengaruhi keyakinan akan kemampuan diri dalam belajar sehingga mereka cenderug pesimis serta tidak memiliki tujuan dalam belajar (Norvenda, Kurniati, dan Rizmahardin, 2018).

Berdasarkan hasil wawancara siswa diperoleh bahwa siswa dengan self-efficacy rendah pada aspek strength menandakan bahwa siswa tidak dapat bertahan ketika menghadapi kegaglan atau hambatan sehingga mereka masih ragu dan tidak yakin terhap kemampuan diri dalam belajar. Siswa dengan self-efficacy tinggi akan meningkatkan usahanya ketika mengalami kegagalan. Sedangkan siswa dengan self-efficacy rendah menandakan siswa tidak dapat bertahan ketika menghadapi hambatan.

Self-efficacy menandakan siswa tidak dapat bertahan ketika menghadapi hambatan atau kegagalan. Siswa mudah terpengaruh oleh lingkungan yang mempengaruhi keyakinan akan kemampuan dirinya sehingga mereka cenderung ragu dan menjadi pesimis serta tidak memiliki usaha yang tinggi dalam upaya mencapai tujuan dalam belajar (Novenda, Kurniati, dan Rizmahardian, 2018).

Hasil analisis angket motivasi belajar. Hasil analisis angket motivasi belajar yang dilakukan pada sampel yang berjumlah 180 siswa dapat dilihat pada Gambar 3. Hasil analisis angket motivasi belajar siswa kelas XI SMA Negeri 14 Pekanbaru dalam pembelajaran Biologi memilki rata-rata 72,23\% pada kategori baik. Hal ini menunjukkan bahwa masih ada siswa yang memiliki motovasi belajar yang baik. Hal ini dapat dilihat dari 6 indikator motivasi belajar. 


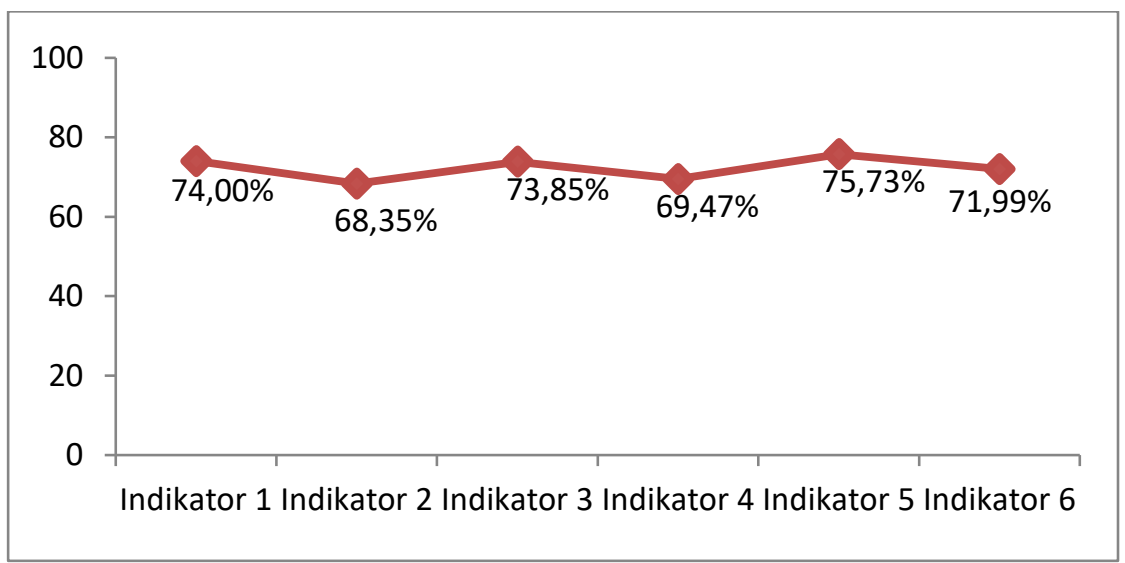

Gambar 3. Persentase Seluruh Indikator Motivasi Belajar

Hubungan self-efficacy dan Motivasi Belajar. Hubungan self-efficacy terhadap motivasi belajar Biologi siswa kelas XI SMA Negeri 14 Pekanbaru diketahui dengan melakukan analisi korelasi. Peneliti menggunakan rumus korelasi product moment dah hasil dari analisis didapat bahwa koefesien korelasi ( $\mathrm{r}_{\text {hitung }}$ ) sebesar 0,22 dengan taraf signifikan 5\% hal ini menunjukkan bahwa self-efficacy terhadap motivasi belajar Biologi kelas XI SMA Negeri 14 Pekanbaru memiliki korelasi dalam kategori rendah.

Pengujian hipotesis pada penelitian ini diperoleh $t_{\text {hitung }}(3,08)<t_{\text {tabel }}(1,66)$. Hal ini berarti $\mathrm{H}_{\mathrm{o}}$ ditolak dan $\mathrm{H}_{\mathrm{a}}$ diterima "Terdapat Hubungan Yang Signifikan Antara Self Efficacy Terhadap Motivasi Belajar Biologi Siswa Kelas XI SMA Negeri 14 Pekanbaru Tahun Ajaran 2020/2021”. Kemudian dari hasil analisis korelasi determinasi diperoleh sebesar 5\%, artinya variabel self-efficacy (X) memberikan sumbangan positif terhadap motivasi belajar (Y) yang diperoleh sebesar 5\% sedangkan 95\% ditentukan oleh variabel atau faktor lain yang dapat mempengaruhi motivasi belajar siswa yang tidak dibahas dalam penelitian ini.

Self-efficacy secara keseluruhann sangat memberikan pengaruh positif terhadap peningkatan motivasi belajar Biologi. Proses berfikir yang melibatkan faktor internal dapat membentuk self-efficacy siswa yang mendorong untuk tumbuhnya motivasi belajar siswa. Adanya self-efficacy yang baik maka akan membantu siswa untuk mencapai motivasi belajar yang baik sehingga siswa dapat menyelesaikan tugasnya secara optimal dalam mencapai prestasi belajar disekolah. Selain itu siswa juga dapat mengubah tingkah laku yang lebih baik lagi dari yang sebelumnya, sehingga motivasi belajar akan lebih meningkat dan berkembang.

Self-efficacy yang tinggi akan dapat mempengaruhi proses pembelajaran siswa di lingkungan pendidikannya. Kemudian, self-efficacy sangat perlu ditingkatkan untuk mencapai pendidikan yang merata dalam proses pembelajaran mahasiswa (Sagita, 2017). Rendahnya self-efficacy dapat berpengaruh terhadap motivasi belajar siswa. Adanya kepercayaan diri yang dimiliki siswa akan kemampuannya, maka siswa akan memotivasi dirinya sendiri ketika menyelesaikan persoalan yang mereka hadapi. Keyakinan diri yang ada pada siswa dapat menumbuhkan keinginan yang kuat untuk memotivasi diri ketika melaksanakan aktivitas belajar.

Selain self-efficacy masih banyak faktor lain yang mempengaruhi motivasi belajar. Faktor-faktor yang mempengaruhi motivasi belajar siswa diantaranya adalah, faktor Intrinsik: motivasi intrinsik adalah suatu bentuk motivasi yang berasal dari dalam diri individu dalam menyikapi suatu tugas dan pekerjaan yang diberikan kepada individu dan membuat tugas dan pekerjaan tersebut dapat memberikan kepuasan batin bagi 
individu sendiri (Sardiman, 2018). Selain itu ada juga faktor ekstrinsik: motivasi ekstrinsik adalah motif yang timbul karena adanya rangsangan dari luar individu, misalnya dalam bidang pendidikan terdapat minat yang positif terhadap kegiatan pendidikan yang timbul karena melihat manfaatnya (Uno, 2019).

\section{SIMPULAN}

Berdasarkan hasil analisis data penelitian dapat disimpulkan bawah terdapat hubungan self-efficacy terhadap motivasi belajar Biologi kelas XI SMA Negeri 14 Pekanbaru Tahun ajaran 2020/2021 dengan kategori rendah sebesar 0,22.

\section{DAFTAR RUJUKAN}

Aryanti, Y. D., \& Muhsin. (2020). Pengaruh Efikasi Diri, Perhatian Orang Tua, Iklim Kelas dan Kreativitas Mengajar terhadap Motivasi Belajar Siswa. Economic Education Analysis Journal, 9(1), 243-260.

Amir, Z, dan Risnawati. (2015). Psikologi Pembelajaran Matematika. Yogyakarta: Aswaja Pressindo.

Emda. (2017). Kedudukan Motivasi Belajar Siswa Dalam Pembelajaran. Lantanida Journal, 5(2), 93-196.

Fajarwati, I. (2016). Pengaruh Peranan Guru Dan Efikasi Diri Siswa Pemasaran Siswa Kelas X Pemasaran. Jurnal Penelitian dan Pendidikan IPS (JPPI), 10(2), 233244.

Ghufron M. Nur, \& Risnawati R.S. (2017). Teori-Teori Psikologi. Yogyakarta: Ar-Ruzz Media.

Hartono. (2015). Statistik untuk Penelitian. Pekanbaru: Zanafa.

Hikmawati, F. (2019). Metode Penelitian. Depok: Rajawali Pers.

Kompri. (2016). Motivasi Pembelajaran. Bandung: PT Remaja Rosdakarya Offset.

Kristiyani, T. (2016). Self Regulated Learning. Yogyakarta: Sanata Sharma University Press.

Monika, M., \& Adman, A. (2017). Peran Efikasi Diri Dan Motivasi Belajar Dalam Meningkatkan Hasil Belajar Siswa Sekolah Menengah Kejuruan. Jurnal Pendidikan Manajemen Perkantoran, 2(2), 109.

Novanda, B. F. (2018). Hubungan Antara Self-Efficacy Dan Motivasi Berprestasi Siswa Kelas Xi Ipa Dalam Mata Pelajaran Kimia Di Sma Negeri 3 Pontianak. AR-RAZI Jurnal Ilmiah, 6(2), 8-17.

Pane, A., \& Darwis Dasopang, M. (2017). Belajar Dan Pembelajaran. FITRAH:Jurnal Kajian Ilmu-ilmu Keislaman, 3(2), 333. https://doi.org/10.24952/fitrah.v3i2.945

Riduwan. (2015). Belajar Mudah Penelitian untuk Guru-Karyawan dan Peneliti Pemula. Bandung: Alfabeta.

Riduwan. (2016). Dasar-Dasar Statistik. Bandung: Alfabeta.

Sundayana, R. (2014). Statistika Penelitian Pendidikan. Bandung: Alfabeta.

Sudijono. (2018). Pengantar Statistik Pendidikan. Jakarta: Rajawali Press.

Sugiyono. (2019). Metode Penelitian Kuantitatif, Kualitatif, dan R\&D. Bandung: Alfabeta

Sudaryono. (2019). Metodelogi Penelitian. Depok: Rajawali Pers

Sardiman, A. M. (2019). Interaksi dan Motivasi Belajar Mengajar. Jakarta: Rajawali Pers

Suryani, L., Seto, S. B., \& Bantas, M. G. D. (2020). Hubungan Efikasi Diri dan Motivasi Belajar Terhadap Hasil Belajar Berbasis E-Learning pada Mahasiswa Program 
Studi Pendidikan Matematika Universitas Flores. Jurnal Kependidikan: Jurnal Hasil Penelitian dan Kajian Kepustakaan di Bidang Pendidikan, Pengajaran dan Pembelajaran, 6(2), 275.

Uno, H. (2019). Teori Motivasi \& Pengukurannya. Jakarta: Bumi Aksara

Widyaning, S. (2017). Hubungan Efikasi Diri Dengan Kecemasan Menghadapi Ujian Nasional Pada Siswa. Happiness, 1(2), 111-124.

Yunanti, E. (2016). Hubungan Antara Kemampuan Metakognitif Dan Motivasi Belajar Dengan Hasil Belajar Biologi Kelas Ix Mts N Metro Tahun Pelajaran 2013/2014. BIOEDUKASI (Jurnal Pendidikan Biologi), 7(2), 81-89. https://doi.org/10.24127/bioedukasi.v7i2.609

Zega, Y. (2020). Hubungan Self Efficacy Terhadap Motivasi Belajar Dalam Pembelajaran Matematika. Didaktik, 14(1), 2410-2416. 